\title{
Body mass index change during adulthood and risk of oesophageal squamous-cell carcinoma in a Japanese population: the Japan Public Health (JPHC)-based prospective study
}

Huan Song ${ }^{1,2,3}$, Eiko Saito ${ }^{2,4,5}$, Norie Sawada ${ }^{4}$, Sarah K Abe ${ }^{6}$, Akihisa Hidaka ${ }^{4}$, Taichi Shimazu ${ }^{4}$, Taiki Yamaji ${ }^{4}$, Atsushi Goto ${ }^{4}$, Motoki Iwasaki ${ }^{4}$, Shizuka Sasazuki ${ }^{4}$, Weimin Ye ${ }^{1}$, Manami Inoue ${ }^{\star, 2,4}$ and Shoichiro Tsugane ${ }^{\star, 4}$ for the Japan Public Health Center-based Prospective Study group ${ }^{7}$

${ }^{1}$ Department of Medical Epidemiology and Biostatistics, Karolinska Institutet, Stockholm, Sweden; ${ }^{2}$ AXA Department of Health and Human Security, Graduate School of Medicine, The University of Tokyo, 7-3-1 Hongo, Bunkyo-ku, Tokyo 113-0033, Japan; ${ }^{3}$ Centre of Public Health Sciences, Faculty of Medicine, University of Iceland, Reykjavik, Iceland; ${ }^{4}$ Epidemiology and Prevention group, Center for Public Health Sciences, National Cancer Center, 5-1-1 Tsukiji Chuo-ku, Tokyo 104-0045, Japan; ${ }^{5}$ Division of Cancer Statistics Integration, Center for Cancer Control \& Information Services, National Cancer Center, 5-1-1 Tsukiji Chuo-ku, Tokyo 104-0045, Japan and ' Department of Global Health Policy, Graduate School of Medicine, The University of Tokyo, 7-3-1 Hongo, Bunkyo-ku, Tokyo 113-0033, Japan

Background: The influence of body mass index (BMI) change during adulthood on the development of oesophageal squamouscell carcinoma (ESCC) is unknown.

Methods: Based on the Japan Public Health Center-based Prospective Study, we enrolled 103238 participants from 1990 to 1994. Anthropometric data at age 20 years, baseline, and 5- and/or 10-year follow-up surveys were collected by questionnaire. The effect of $\mathrm{BMI}$ change between age 20 years and baseline on ESCC risk was estimated by Cox proportional hazards regression models. The updated BMI was taken into account by fitting a simple linear regression model for each individual, where the slope was incorporated into regressions as a time-varying variable.

Results: After excluding the first 5 years of observation, we identified 342 newly diagnosed ESCC cases. An increase in BMI during adulthood was linked with a decreased risk of ESCC development, with each 1\% increase per 5 years corresponding to a 15\% decrease in ESCC risk (95\% confidence interval 9-21\%). Identical estimates were obtained from time-dependent models. The importance of BMl change was not modified by gender, smoking, or alcohol drinking but confined to participants assessed as non-overweight at baseline.

Conclusions: An increase in BMI during adulthood is associated with a lower risk of developing ESCC among non-overweight subjects.

\footnotetext{
*Correspondence: Dr M Inoue; E-mail: mnminoue@m.u-tokyo.ac.jp or Dr S Tsugane; E-mail: stsugane@ncc.go.jp 7.JPHC Study Group members are listed at http://epi.ncc.go.jp/en/jphc/781/3838.html.
}

Received 10 April 2017; revised 2 August 2017; accepted 30 August 2017; published online 26 September 2017

(C) 2017 Cancer Research UK. All rights reserved 0007-0920/17 
According to 2012 data, oesophageal cancer is the eighth most common cancer and sixth leading cause of cancer-related death worldwide (Ferlay et al, 2015). Among Asian populations, the predominant histological type is oesophageal squamous-cell carcinoma (ESCC), which is distinct from the other major type, oesophageal adenocarcinoma, in terms of aetiology and epidemiology. To date, established primary risk factors for ESCC are smoking, alcohol abuse, and low fruit/vegetable intake (Engel et al, 2003; Bahmanyar and Ye, 2006). Results for other possible risk factors, such as low socioeconomic status, hot beverage drinking, and poor oral hygiene, have been less convincing (Taylor et al, 2003; Abnet et al, 2005; Pennathur et al, 2013).

Excess body mass index (BMI), especially obesity, has long been identified as a risk factor for many adverse health outcomes, including cancers at many sites (Bianchini et al, 2002; Yang et al, 2009; Kruk, 2014). For ESCC, however, the opposite risk pattern has been consistently observed among different populations, albeit to a varied extent (Resl and Zouhar, 1983; Engeland et al, 2004; Tran et al, 2005; Smith et al, 2008; Lahmann et al, 2012). These studies imply an intriguing and seemingly robust inverse association between BMI and ESCC development. However, given that weight loss might itself owe to latent cancer (early symptom of undiagnosed ESCC) and the fact that analysis using BMI at an early age (e.g., 20 years; Lahmann et al, 2012) did not show similar results, it remains unclear whether increased BMI does in fact protect against the development of ESCC. Moreover, considering that BMI naturally varies with age, estimates derived from cross-sectional anthropometric assessment (i.e., weight and height measured at a single time point) are deemed inaccurate, impending further application to risk stratification. In addition, insights into the relationship between patterns of BMI change and ESCC risk might aid understanding of the mechanisms underlying the observed BMI-related effects.

Here, using a large prospective population-based cohort study in Japan with up to four self-reported BMI measures (at age of 20 years, baseline interview, as well as at 5 and 10 years of follow-up), we evaluated the association of BMI and changes in BMI during adulthood with the risk of developing ESCC among a Japanese population.

\section{MATERIALS AND METHODS}

Database and study design. Our project was based on the use of data from the Japan Public Health Center-based Prospective Study (JPHC Study), which enrolled 140420 registered residents aged 40-69 years within 11 public health centre (PHC) areas nationwide from 1990 to 1994. Among 112890 participants (response rate $81 \%$ ) with available baseline questionnaire information, $80 \%$ and $76 \%$ have updated data from the fifth and tenth year of follow-up, respectively. Details of this study have been described elsewhere (Tsugane and Sawada, 2014). For each survey, comprehensive information regarding personal and family medical history, lifestyle, psychosocial factors, and anthropometric indexes was collected using a self-administrated questionnaire.

In the present study, we recruited participants who responded to the baseline survey (Figure 1). We excluded subjects with a selfreported history of cancer $(n=2539)$ and those who died or moved out of the study area $(n=86)$ before baseline enrollment (study entry, defined as the date of submission of the baseline questionnaire). We further excluded 29 subjects with missing values for baseline BMI, as well as the 6988 subjects from the Katsushika health centre, for whom cancer incidence data were not available. Finally, 103238 participants were recruited to the study cohort. Follow-up for these subjects continued until first cancer diagnosis, moving out of the study area, death, or the end of follow-up (2012-12-31), whichever occurred first. This study was
140420 registered residents aged $40-$ 69 years within 11 public health centre areas nationwide from 1990 to 1994

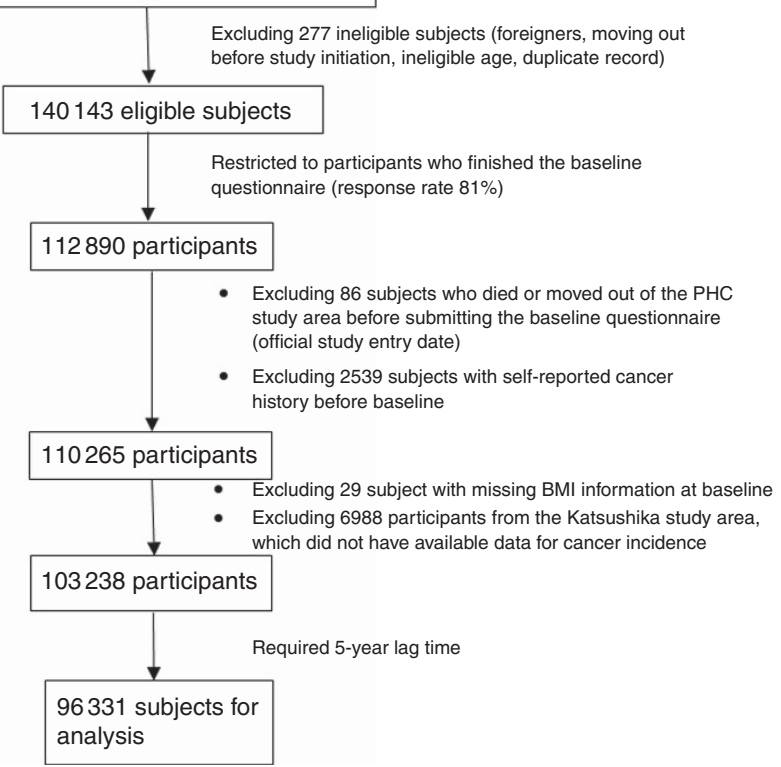

Figure 1. Study design.

approved by the institutional review boards of the National Cancer Center and the University of Tokyo.

Anthropometric data. All participants were required to report their height and current weight at baseline. Updated data on weight was also available for most of those who responded to the 5-/10year follow-up surveys. In addition to weight at the time of interview, the baseline questionnaire collected in 1990 (JPHC cohort I) requested participants to classify their change in weight since age 20 years into three groups: decreased $>5 \mathrm{~kg}$, varied within $5 \mathrm{~kg}$, or increased $>5 \mathrm{~kg}$. Participant's weight at age 20 years was obtained in the questionnaire collected at baseline in 1993/1994 (JPHC cohort II) or at the 10-year follow-up (for those without such information at the baseline survey).

We calculated BMI values by dividing weight in kilograms $(\mathrm{kg})$ by height in metres $(\mathrm{m})$ squared and categorised results according to the international classification in the World Health Organisation guideline (BMI level: underweight $<18.5$, normal 18.5-24.9, overweight $25.0-29.9$, and obesity $\geqslant 30 \mathrm{~kg} \mathrm{~m}^{-2}$ ).

Cancer case ascertainment. Cancer cases were captured through data linkage with cancer registries and/or notification from local hospitals in the study areas. We identified ESCC using the International Classification of Disease for Oncology, Third Edition (ICD-O-3) code 'C15' with histology code 8050-8084 (WHO, 2000).

Statistical analysis. As weight loss is itself an early symptom of ESCC, we excluded the first 5-year follow-up and events detected during this period from all analyses (5-year lag time). The relative risk of having an ESCC diagnosis in relation to BMI was estimated with a Cox regression model, expressed as hazard ratio (HR) with 95\% confidence intervals (CIs). We used time since study entry as the underlying timescale. The model was adjusted for age at entry, gender (female/male), smoking status (never, former, or current smoker), alcohol consumption (never, rare, <23, 23-46, 47-69, $70-92$, or $>92 \mathrm{gday}^{-1}$ ), occupation (professional, sales clerk, farmer, other, or unemployed), physical activity (almost none, 1-3 times per month, 1-2 times per week, 3-4 times per week, or almost every day), living arrangement (living alone/with others), fruit and vegetable intake level (by quartiles), family history of 
cancer (yes/no), and stratified by PHC area. We evaluated ESCC risk associated with BMI level at baseline, BMI level at age 20 years, and BMI change between age 20 years and baseline separately. Change in BMI was first grouped according to the way defined in the Cohort I baseline questionnaire (decreased $>5 \mathrm{~kg}$, varied within $5 \mathrm{~kg}$, or increased $>5 \mathrm{~kg}$ ). We then further quantified the change in BMI by percentage (\%) per 5 years, adding it to the Cox model as either a continuous variable or category by quartile. For categorical variables, we always treated the subgroup representing the most natural condition (i.e., normal BMI level, varied within $5 \mathrm{~kg}$, or the second quartile of BMI change over time) as the reference group. $P$-values for linear trends were calculated by assigning ordinal variables for gradually increased BMI level/ change in BMI and entering the number as a continuous variable into the model. We checked the proportional hazards assumption graphically and using Schoenfeld partial residuals, and no indication of violation was seen.

Furthermore, among subjects with valid BMI at baseline and age 20 years, $80.2 \%$ had at least one re-evaluation of BMI in either the fifth or tenth year of follow-up, and $67.9 \%$ had re-evaluation in both follow-ups. To handle these updated BMI information (if any), we fitted a simple linear regression model for each individual using age as exposure and BMI change in percentage ((BMI at age of interview - BMI at age of 20 years)/BMI at age of 20 years) as outcome. The slopes $(\times 5$, indicating change in BMI in $\%$ per 5 years) in these regressions were used as measures of BMI change in a time-varying Cox regression model, in which the updated slope value replaced the old one after the date of follow-up data collection. Again, to ensure the irrelevance of BMI changes to latent ESCC, updated BMI information in the 5 years preceding an ESCC diagnosis was discarded for the time-varying analysis.

We next conducted a subgroup analysis by BMI level at baseline ( $<$ or $\geqslant 25 \mathrm{~kg} \mathrm{~m}^{-2}$ ), gender, smoking status, and alcohol consumption level to detect possible effect modification. In particular, to minimise residual confounding, the degree of smoking (by pack-years) and alcohol consumption (by g per week) was considered in subanalyses focussing on smokers and alcohol drinkers. The significance of the interaction was statistically checked by involving the cross-product terms of BMI and subgrouping variables into the models.

Finally, given our specific concern about missing BMI data at age 20 years ( $16.7 \%$ of all analysed participants) and consequent analysis of BMI change with incomplete data sets, we performed a sensitivity analysis based on multiple imputation using the multivariate normal distribution method (SAS statistical software, version 9.4, SAS, Cary, NC, USA, PROC MI). Besides the imputed variable (BMI change in \% per 5 years), the imputation models included all covariates that were possibly predictive of the missing data, together with the outcome variable (ESCC) and exposure time variable (person-years at risk) (Sterne et al, 2009). We created 20 imputed data sets. Pooled estimates from multiple imputation analyses were then compared with results from complete case analyses (our main analysis of BMI change) to reflect the uncertainty associated with the imputed variable.

All analyses were conducted using SAS statistical software, version 9.4 (SAS). A $P$-value $<0.05$ was considered statistically significant.

\section{RESULTS}

After excluding the first 5 years of follow-up, 96331 subjects were eventually included in the analysis, contributing a total of 1278448 person-years at risk. Table 1 displays the basic characteristics of these subjects and their distribution among different baseline BMI groups. Mean age at study entry was 53 years. There was an overall predominance of women (male: female $=1: 1.14$ ). Alcohol consumption was more frequent among persons with a normal BMI at baseline compared with other baseline BMI groups, while the proportion of current smokers notably declined with increased BMI. In addition, we observed a relatively high proportion of unfavourable life profiles among underweight participants, that is, low vegetable/fruit consumption amount, unemployment, and physical inactivity, whereas these factors were more comparable for all other BMI level groups.

During follow-up, 342 participants, including 37 females, received a diagnosis of ESCC. Table 2 illustrates the distribution of ESCC cases across different BMI level groups along with adjusted HRs for between-group comparisons using Cox regression models. Intriguingly, using a normal BMI level as reference, the hazards for ESCC increased (albeit not significantly) with higher BMI level at age 20 years $(P$ for trend $=0.0032)$ but conversely decreased with elevated BMI level at age of interview ( $P$ for trend $=0.0013$ ). Owing to a limited number of ESCC cases, these trends were less clear for females.

With regard to the change in weight/BMI between age 20 years and baseline interview, we generally found that an increase in weight or BMI was consistently linked with lower ESCC incidence (Table 3). This dose-response relationship was most obvious when BMI change was measured as a continuous variable (\% per 5 years). Time-varying analyses that allowed the adjustment of slope (rate of change in BMI) by follow-up estimates obtained closely similar results as the baseline analysis - the adjusted HRs was 0.85 (95\% CI 0.79-0.91) for BMI change between age 20 years and baseline, which then altered to 0.86 (95\% CI $0.81-0.92$ ) when follow-up BMI data were taken into account. On further stratification by gender, with variation in effect sizes, identical trends were observed among both males and females (Table 3).

Notably, on stratification by BMI level at baseline, these results above remained valid only for participants with a BMI of $<25 \mathrm{~kg} \mathrm{~m}^{-2}$ at baseline. In contrast, for overweight or obese subjects, underweight at age 20 years was significantly associated with a threefold increase in ESCC risk compared with those with a normal BMI when young (Table 4). Likewise, the importance of BMI change during adulthood seemed to be obscure in the case of subjects who had reached 'overweight' at the time of baseline interview.

With regard to smoking status, although point estimates of BMI showed mixed effects on ESCC risk between subgroups, BMI changes measured by the defined unit (\% per 5 year) consistently indicated adverse associations between BMI change and ESCC risk (Supplementary Table 1). Stratification of alcohol consumption (non-drinker, low level $\left(<46 \mathrm{~g}\right.$ day $\left.^{-1}\right)$, or high level $\left(\geqslant 46 \mathrm{~g} \mathrm{day}^{-1}\right)$ alcohol drinker) did not modify the results observed in the main analyses (Supplementary Table 2).

Results of sensitivity analyses, in which missing data on BMI change between the age of interview and age 20 years were handled by multiple imputation, were closely similar to those of the main analysis: an increase of one defined unit (\% per 5 years) in BMI was linked with a $14 \%$ lower risk of having an ESCC diagnosis ( $\mathrm{HR}=0.86,95 \%$ CI $0.79-0.93)$; grouped by quartile, compared with the second quartile (BMI changed from 0 to $+1.36 \%$ per 5 years), the first $(<0 \%)$, third (from +1.37 to $+3.0 \%)$, and fourth $(>+3.0 \%)$ quartile group corresponded to HRs of 1.19 (95\% CI $0.88-1.60$ ), 0.75 (95\% CI 0.53-1.08), and 0.59 (95 CI\% 0.38-0.94), respectively.

\section{DISCUSSION}

Only until recently, studies of BMI and cancer incidence attempted to use longitudinal data on weight for association assessment (Han 
Table 1. Characteristics of participants, overall and stratified by body mass index (BMI) level at baseline with 5-year lag time

\begin{tabular}{|c|c|c|c|c|c|}
\hline & & \multicolumn{4}{|c|}{ BMI level at baseline } \\
\hline & Overall & $<18.5 \mathrm{~kg} \mathrm{~m}^{-2}$ & $18.5-24.9 \mathrm{~kg} \mathrm{~m}^{-2}$ & $25-29.9 \mathrm{~kg} \mathrm{~m}^{-2}$ & $\geqslant 30.0 \mathrm{~kg} \mathrm{~m}^{-2}$ \\
\hline Total $n$ & 96331 & 4126 & 65834 & 23867 & 2504 \\
\hline Age at baseline, mean \pm s.d. & $52.7 \pm 8.0$ & $53.9 \pm 9.0$ & $52.5 \pm 8.1$ & $53.0 \pm 7.6$ & $53.0 \pm 7.6$ \\
\hline $\begin{array}{l}\text { Years of follow-up }{ }^{a} \text {, } \\
\text { mean } \pm \text { s.d. }\end{array}$ & $13.3 \pm 4.1$ & $12.4 \pm 4.5$ & $13.3 \pm 4.1$ & $13.4 \pm 4.1$ & $13.2 \pm 4.1$ \\
\hline Sex, $n(\%)$ of males & $45119(46.8)$ & $1664(40.3)$ & $31074(47.2)$ & $11471(48.1)$ & $910(36.3)$ \\
\hline $\begin{array}{l}\text { Alcohol consumption } \\
\text { Never } \\
\text { Rare }<1 \text { time per week } \\
<23 \mathrm{~g} \text { day }^{-1} \\
23-46 \mathrm{~g} \text { day }^{-1} \\
47-69 \mathrm{~g} \text { day }^{-1} \\
70-92 \mathrm{~g} \text { day }^{-1} \\
>92 \mathrm{~g}^{-1} \mathrm{day}^{-1} \\
\text { Missing }\end{array}$ & $\begin{aligned} 48952(50.8) \\
9071(9.4) \\
7274(7.5) \\
11177(11.6) \\
8267(8.6) \\
5649(5.9) \\
4454(4.6) \\
1487(1.5)\end{aligned}$ & $\begin{array}{l}2388(57.9) \\
273(6.6) \\
316(7.7) \\
429(10.4) \\
265(6.4) \\
171(4.1) \\
126(3.1) \\
158(3.8)\end{array}$ & $\begin{array}{l}32790(49.8) \\
6101(9.3) \\
5344(8.1) \\
8048(12.2) \\
5970(9.1) \\
3924(5.9) \\
2733(4.2) \\
924(1.4)\end{array}$ & $\begin{array}{l}12269(51.4) \\
2414(10.1) \\
1513(6.3) \\
2530(10.6) \\
1915(8.0) \\
1449(6.1) \\
1423(6.0) \\
354(1.5)\end{array}$ & $\begin{array}{l}1505(60.1) \\
283(11.3) \\
101(4.0) \\
170(6.8) \\
117(4.7) \\
105(4.2) \\
172(6.9) \\
51(2.0)\end{array}$ \\
\hline $\begin{array}{l}\text { Smoking status } \\
\text { Non-smoker } \\
\text { Former smoker } \\
\text { Current smoker } \\
\text { Missing }\end{array}$ & $\begin{array}{c}57675(59.9) \\
11357(11.8) \\
26814(27.8) \\
485(0.5)\end{array}$ & $\begin{aligned} 2415 & (58.5) \\
347 & (8.4) \\
1246 & (30.2) \\
118 & (2.9)\end{aligned}$ & $\begin{array}{c}38813(59.0) \\
7544(11.5) \\
19223(29.2) \\
254(0.4)\end{array}$ & $\begin{array}{c}14751(61.8) \\
3185(13.3) \\
5829(24.4) \\
102(0.4)\end{array}$ & $\begin{array}{c}1696(67.7) \\
281(11.2) \\
516(20.6) \\
11(0.4)\end{array}$ \\
\hline $\begin{array}{l}\text { Fruit intake amount } \\
\text { First quartile (lowest) } \\
\text { Second quartile } \\
\text { Third quartile } \\
\text { Fourth quartile (highest) }\end{array}$ & $\begin{array}{l}27913(29.0) \\
21589(22.4) \\
22821(23.7) \\
24008(24.9)\end{array}$ & $\begin{array}{l}1369(33.2) \\
922(22.4) \\
915(22.2) \\
920(22.3)\end{array}$ & $\begin{array}{l}18612(28.3) \\
14770(22.4) \\
15750(23.9) \\
16702(25.4)\end{array}$ & $\begin{array}{l}7079(29.7) \\
5368(22.5) \\
5555(23.3) \\
5865(24.6)\end{array}$ & $\begin{array}{l}853(34.1) \\
529(21.1) \\
601(24.0) \\
521(20.8)\end{array}$ \\
\hline $\begin{array}{l}\text { Vegetable intake amount } \\
\text { First quartile (lowest) } \\
\text { Second quartile } \\
\text { Third quartile } \\
\text { Fourth quartile (highest) }\end{array}$ & $\begin{array}{l}25576(26.6) \\
24763(25.7) \\
14567(15.1) \\
31425(32.6)\end{array}$ & $\begin{array}{c}1365(33.1) \\
1153(27.9) \\
582(14.1) \\
1026(24.9)\end{array}$ & $\begin{array}{l}17179(26.1) \\
16970(25.8) \\
9902(15.0) \\
21783(33.1)\end{array}$ & $\begin{array}{l}6310(26.4) \\
6009(25.2) \\
3687(15.5) \\
7861(32.9)\end{array}$ & $\begin{array}{l}722(28.8) \\
631(25.2) \\
396(15.8) \\
755(30.2)\end{array}$ \\
\hline $\begin{array}{l}\text { Occupation } \\
\text { Professional or office worker } \\
\text { Sales clerk or other } \\
\text { Farmer } \\
\text { Other } \\
\text { Unemployed incl. housewife } \\
\text { Missing }\end{array}$ & $\begin{array}{l}23005(23.9) \\
21706(22.5) \\
20634(21.4) \\
10051(10.4) \\
19781(20.5) \\
1154(1.2)\end{array}$ & $\begin{array}{c}845(20.5) \\
771(18.7) \\
860(20.8) \\
322(7.80) \\
1153(27.9) \\
175(4.2)\end{array}$ & $\begin{array}{c}15671(23.8) \\
14982(22.8) \\
14002(21.3) \\
7223(11.0) \\
13277(20.2) \\
679(1.0)\end{array}$ & $\begin{array}{c}5943(24.9) \\
5384(22.6) \\
5261(22.0) \\
2329(9.7) \\
4686(19.6) \\
264(1.1)\end{array}$ & $\begin{array}{c}546(21.8) \\
569(22.7) \\
511(20.4) \\
177(7.1) \\
665(26.6) \\
36(1.4)\end{array}$ \\
\hline $\begin{array}{l}\text { Physical activity } \\
\text { Almost none } \\
\text { 1-3 times per month } \\
1-2 \text { times per week } \\
3-4 \text { times per week } \\
\text { Almost everyday } \\
\text { Missing }\end{array}$ & $\begin{array}{c}66915(69.5) \\
10660(11.1) \\
8833(9.8) \\
4059(4.2) \\
4692(4.9) \\
1172(1.2)\end{array}$ & $\begin{array}{l}3026(73.3) \\
296(7.2) \\
255(6.2) \\
134(3.3) \\
207(5.0) \\
208(5.0)\end{array}$ & $\begin{array}{l}45677(69.4) \\
7495(11.4) \\
6145(9.3) \\
2702(4.1) \\
3115(4.7) \\
700(1.1)\end{array}$ & $\begin{array}{l}16430(68.8) \\
2639(11.1) \\
2242(9.4) \\
1110(4.6) \\
1220(5.1) \\
226(1.0)\end{array}$ & $\begin{array}{l}1782(71.2) \\
230(9.2) \\
191(7.6) \\
113(4.5) \\
150(6.0) \\
38(1.5)\end{array}$ \\
\hline $\begin{array}{l}\text { Family history of cancer } \\
\text { (parents/siblings) } \\
\text { No } \\
\text { Yes }\end{array}$ & $\begin{array}{l}75743(78.6) \\
20588(21.4)\end{array}$ & $\begin{array}{l}3262(79.1) \\
864(20.9)\end{array}$ & $\begin{array}{l}51588(78.4) \\
14246(21.6)\end{array}$ & $\begin{array}{l}18867(79.1) \\
5000(21.0)\end{array}$ & $\begin{array}{c}2026(80.9) \\
478(19.1)\end{array}$ \\
\hline $\begin{array}{l}\text { Living arrangement: living } \\
\text { alone } \\
\text { No } \\
\text { Yes } \\
\text { Missing }\end{array}$ & $\begin{array}{c}92013(95.5) \\
3632(3.8) \\
686(0.7)\end{array}$ & $\begin{array}{c}3775(91.5) \\
210(5.1) \\
141(3.4)\end{array}$ & $\begin{array}{c}62998(95.7) \\
2425(3.7) \\
411(0.6)\end{array}$ & $\begin{array}{c}22858(95.8) \\
887(3.7) \\
122(0.5)\end{array}$ & $\begin{array}{c}2382(95.1) \\
110(4.4) \\
12(0.5)\end{array}$ \\
\hline
\end{tabular}

et al, 2014; Arnold et al, 2016). However, owing to the low incidence of oesophageal cancer, particularly ESCC, among western populations, most western cohorts are not capable of addressing the question of whether ESCC risk is related to BMI change during adulthood (Han et al, 2014; Arnold et al, 2016). Our research, the first large population-based cohort study that assessed ESCC risk using up to four self-reported BMI measures among 103238 participants with an average follow-up of 13 years, indicates that while BMI at recruitment was inversely associated with ESCC risk, BMI level at a young age showed the opposite effect. Nevertheless, when focussing on the effects of BMI change during adulthood, an increase in BMI was consistently associated with a decreased risk of ESCC among this non-overweight Japanese population. Given the application of 5-year lag time for all analyses, the completeness of covariate information, as well as rigorous control for other important risk factors such as smoking status or alcohol consumption, the observed associations in our study cannot be explained by either reverse causality or 
Table 2. Hazard ratios (HRs) and $95 \%$ confidence intervals (Cls) for oesophageal squamous-cell carcinoma in relation to body mass index, overall and stratified by gender

\begin{tabular}{|c|c|c|c|c|c|c|c|c|c|}
\hline & \multicolumn{3}{|c|}{ All $(n=96331)$} & \multicolumn{3}{|c|}{ Males $(n=45119)$} & \multicolumn{3}{|c|}{ Females $(n=51212)$} \\
\hline $\begin{array}{l}\text { Body mass } \\
\text { index level }\end{array}$ & $\begin{array}{c}\text { Observed } \\
\text { cases }^{a}\end{array}$ & $\begin{array}{l}\text { Person- } \\
\text { years at } \\
\text { risk }^{a}\end{array}$ & $\begin{array}{l}\mathrm{HR} \text { and } 95 \% \\
\mathrm{Cl}^{\mathrm{b}}\end{array}$ & $\begin{array}{c}\text { Observed } \\
\text { cases }^{a}\end{array}$ & $\begin{array}{l}\text { Person- } \\
\text { years at } \\
\text { risk }^{a}\end{array}$ & $\begin{array}{l}\mathrm{HR} \text { and } 95 \% \\
\mathrm{Cl}^{\mathrm{b}}\end{array}$ & $\begin{array}{c}\text { Observed } \\
\text { cases }^{a}\end{array}$ & $\begin{array}{l}\text { Person- } \\
\text { years at } \\
\text { risk }^{a}\end{array}$ & $\begin{array}{l}\mathrm{HR} \text { and } 95 \% \\
\mathrm{Cl}^{\mathrm{b}}\end{array}$ \\
\hline \multicolumn{10}{|c|}{ At the time of baseline interview } \\
\hline $\begin{array}{l}<18.5 \mathrm{~kg} \mathrm{~m}^{-2} \\
18.5-24.9 \mathrm{~kg} \mathrm{~m}^{-2} \\
25-29.9 \mathrm{~kg} \mathrm{~m}^{-2} \\
\geqslant 30.0 \mathrm{~kg} \mathrm{~m}^{-2} \\
P \text { for trend }\end{array}$ & $\begin{array}{c}12 \\
274 \\
52 \\
4\end{array}$ & $\begin{array}{c}51166 \\
873708 \\
320531 \\
33043\end{array}$ & $\begin{array}{l}0.87(0.48-1.56) \\
\text { Reference } \\
0.57(0.42-0.77) \\
0.60(0.22-1.61) \\
0.0013\end{array}$ & $\begin{array}{c}11 \\
242 \\
48 \\
4\end{array}$ & $\begin{array}{c}19442 \\
396821 \\
149551 \\
11549\end{array}$ & $\begin{array}{c}0.95(0.52-1.75) \\
\text { Reference } \\
0.60(0.44-0.82) \\
0.74(0.27-2.01) \\
0.0052\end{array}$ & $\begin{array}{c}1 \\
32 \\
4 \\
0\end{array}$ & $\begin{array}{c}31724 \\
476887 \\
170980 \\
21494\end{array}$ & $\begin{array}{c}0.45(0.06-3.32) \\
\text { Reference } \\
0.37(0.13-1.06) \\
- \\
0.0992\end{array}$ \\
\hline \multicolumn{10}{|l|}{ At age 20 years } \\
\hline $\begin{array}{l}<18.5 \mathrm{~kg} \mathrm{~m}^{-2} \\
18.5-24.9 \mathrm{~kg} \mathrm{~m}^{-2} \\
25-29.9 \mathrm{~kg} \mathrm{~m}^{-2} \\
\geqslant 30.0 \mathrm{~kg} \mathrm{~m}^{-2} \\
\text { missing } \\
P \text { for trend }\end{array}$ & $\begin{array}{c}15 \\
229 \\
25 \\
4 \\
69\end{array}$ & $\begin{array}{c}98732 \\
894595 \\
82183 \\
8186 \\
194752\end{array}$ & $\begin{array}{c}0.93(0.55-1.58) \\
\text { Reference } \\
1.06(0.70-1.61) \\
1.66(0.62-4.48) \\
1.52(1.15-2.01) \\
0.0032\end{array}$ & $\begin{array}{c}11 \\
211 \\
21 \\
3 \\
59\end{array}$ & $\begin{array}{c}31706 \\
418798 \\
37130 \\
3919 \\
85810\end{array}$ & $\begin{array}{c}0.83(0.45-1.53) \\
\text { Reference } \\
0.96(0.61-1.51) \\
1.33(0.43-4.18) \\
1.44(1.06-1.94) \\
0.0134\end{array}$ & $\begin{array}{c}4 \\
18 \\
4 \\
1 \\
10\end{array}$ & $\begin{array}{c}67026 \\
475797 \\
45053 \\
4267 \\
108942\end{array}$ & $\begin{array}{c}1.63(0.55-4.84) \\
\text { Reference } \\
2.34(0.77-7.07) \\
6.14(0.80-47.0) \\
2.72(1.21-6.12) \\
0.0429\end{array}$ \\
\hline \multicolumn{10}{|c|}{ 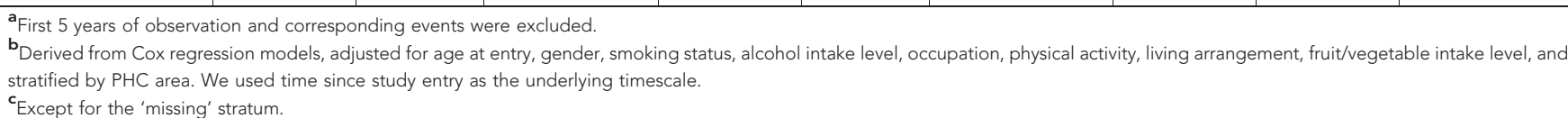 } \\
\hline
\end{tabular}

confounding. Further corroborating the validity and reliability of our findings, sensitivity analyses that effectively managed missing data on BMI change using multiple imputation procedures showed closely similar results to those of the main analysis.

The biological mechanisms of the inverse association between BMI change during adulthood and ESCC development remains unknown. Among many plausible interpretations, poor long-term nutritional status, for which a decrease in BMI can be considered a proxy, might be noteworthy. Unfortunately, dietary data reflecting nutritional condition at a young age are scarce. Previous prospective investigations using cross-sectional dietary intake information collected at the time of participant enrollment found no supportive evidence for an association between fat or protein intake and ESCC risk (Fan et al, 2008; O'Doherty et al, 2012). In contrast, other case-control studies suggested a reduced risk of ESCC among subjects with high intake of carbohydrate (Jessri et al, 2011; Lahmann et al, 2014) or fresh fish (Launoy et al, 1998). These findings need to be verified by prospective data. Alternatively, the pleiotropic capacities of genetic factors (Hu et al, 2016), namely, shared and multifunctional genes and pathways, may contribute to the observed association. However, the change of BMI must be a joint consequence of genetic and environmental (including behavioural) factors; and in the present analyses, as we illustrated a clear temporal sequence, as well as a conspicuous dose-response relationship, between BMI change and ESCC risk, it is less likely the findings can be fully explained by genetic components. Further studies with available genetic data are highly needed.

The differential risk pattern detected using BMI at recruitment and BMI at age 20 years was in line with previous results (Park et al, 2011; Lahmann et al, 2012). This indicates BMI measured closer to the appearance of event (i.e., ESCC) might be a better index for the aforementioned poor nutritional status, compared with BMI of younger age. Also, such differences may help explain the heterogeneity of effect sizes observed in previous observational studies, namely, as partly attributable to the various age ranges of study participants. Furthermore, with little prior knowledge, our results indicate that an increase in BMI of one defined unit (1\% per 5 years) corresponds to a 15\% decrease in the risk of ESCC, with the prerequisite of non-overweightness. This phenomenon, paralleling the finding of a U-shaped association between BMI and mortality among the aged (Tamakoshi et al, 2010; Winter et al,
2014), may imply that weight gain with age, within a healthy range, is actually either beneficial to health or serves as a long-term indicator of a healthy body status.

Importantly, as our efforts of linearly modelling the timevarying rates of BMI change for individuals revealed almost identical results to those of our routine analyses, determining BMI change pattern by two-point assessments (age 20 years and the time of baseline interview) might be sufficient for ESCC risk stratification. In other words, waiting for updated assessment from follow-up surveillance is merely optional. Admittedly, the availability of additional age-specific BMI information from the baseline questionnaire (e.g., at age 20, 30, or 40 years) would allow the BMI trajectory to be tracked more accurately (such as using quadratic growth model; Arnold et al, 2016). However, overuse of retrospective data can also jeopardise the observations by inducing substantial uncertainties owing to recall bias. In addition, expression of BMI change in concrete terms (using '\% per year' as a unit) might help policy makers formulate policies and guidelines for weight management and ESCC risk stratification.

The major strengths of our study are its large sample size, prospective study design, high response rate, and sufficiently long follow-up period. The effectiveness of our measurements is ensured by the full consideration of the latent period of ESCC other studies used a latency period of 1 or 2 years prior to cancer diagnosis vs 5 years here - and the careful control of important confounders, particularly with regard to the degree/amount of smoking or alcohol drinking. Further, the robustness of our findings is supported by the consistent results across all three measures of BMI change, as well as the identical results obtained from multiple imputation analyses.

The possibility of measurement error when BMI values are calculated by self-reported weight and height is a concern. However, self-reported BMIs in the JPHC study were strongly correlated with measured BMIs, with Spearman correlation coefficients of 0.89 for males and 0.91 for females (Matsushita et al, 2008). Additionally, many other large-scale surveys have also applied these self-reported parameters for exploring the association between BMI and oesophageal cancer risk (Abnet et al, 2008; Kort et al, 2009). The possibility of recall bias when BMI at a young age (i.e., 20 years) is obtained retrospectively must be balanced against the strong practical difficulty of enrolling subjects into prospective 
Table 3. Hazard ratios (HRs) and $95 \%$ confidence intervals (Cls) for oesophageal squamous-cell carcinoma in relation to the change in weight or body mass index, overall and stratified by gender

\begin{tabular}{|c|c|c|c|c|c|c|c|c|c|}
\hline \multirow[b]{2}{*}{$\begin{array}{l}\text { Change in } \\
\text { weight or body } \\
\text { mass index } \\
\text { (BMI) over time }\end{array}$} & \multicolumn{3}{|c|}{ All $(n=96331)$} & \multicolumn{3}{|c|}{ Males $(n=45119)$} & \multicolumn{3}{|c|}{ Females $(n=51212)$} \\
\hline & $\begin{array}{c}\text { Observed } \\
\text { cases }^{a}\end{array}$ & $\begin{array}{l}\text { Person- } \\
\text { years } \\
\text { at risk }\end{array}$ & $\begin{array}{l}\text { HR and } 95 \% \\
\mathrm{Cl}^{\mathrm{b}}\end{array}$ & $\begin{array}{l}\text { Observed } \\
\text { cases }^{a}\end{array}$ & $\begin{array}{c}\text { Person- } \\
\text { years } \\
\text { at risk }\end{array}$ & $\begin{array}{l}\text { HR and } 95 \% \\
\mathrm{Cl}^{\mathrm{b}}\end{array}$ & $\begin{array}{l}\text { Observed } \\
\text { cases }^{a}\end{array}$ & $\begin{array}{l}\text { Person- } \\
\text { years } \\
\text { at risk }\end{array}$ & $\begin{array}{l}\text { HR and } 95 \% \\
\mathrm{Cl}^{\mathrm{b}}\end{array}$ \\
\hline \multicolumn{10}{|c|}{ Weight change since age 20 years } \\
\hline $\begin{array}{l}\text { Loss }>5 \mathrm{~kg} \\
\text { Weight varied } \\
\text { within } 5 \mathrm{~kg} \\
\text { Increase }>5 \mathrm{~kg} \\
\text { Missing } \\
P \text { for trend }\end{array}$ & $\begin{array}{c}58 \\
123 \\
92 \\
69\end{array}$ & $\begin{array}{l}111796 \\
386844 \\
548278 \\
231530\end{array}$ & $\begin{array}{c}1.53(1.11-2.11) \\
\text { Reference } \\
0.74(0.55-0.99) \\
1.16(0.83-1.60) \\
0.0002\end{array}$ & $\begin{array}{c}51 \\
113 \\
\\
84 \\
57\end{array}$ & $\begin{array}{c}47184 \\
187508 \\
\\
247023 \\
95648\end{array}$ & $\begin{array}{c}1.47(1.05-2.07) \\
\text { Reference } \\
0.74(0.54-1.01) \\
1.05(0.74-1.49) \\
0.0012\end{array}$ & $\begin{array}{c}7 \\
10 \\
\\
8 \\
12\end{array}$ & $\begin{array}{c}64612 \\
199336 \\
301255 \\
135882\end{array}$ & $\begin{array}{l}1.92(0.70-5.23) \\
\text { Reference } \\
0.70(0.26-1.84) \\
2.40(0.91-6.36) \\
0.0756\end{array}$ \\
\hline $\begin{array}{l}\text { BMI change (\% per } \\
5 \text { years) - between } \\
\text { age } 20 \text { years and } \\
\text { baseline (excluded } \\
\text { missing/extreme } \\
\text { values) }\end{array}$ & & & $0.85(0.79-0.91)$ & & & $0.86(0.80-0.93)$ & & & $0.76(0.62-0.93)$ \\
\hline \multicolumn{10}{|c|}{ BMI change (\% per 5 years) by quartiles - between age 20 years and baseline } \\
\hline $\begin{array}{l}\text { First quartile } \\
(<0 \%)\end{array}$ & 96 & 248623 & $1.13(0.84-1.52)$ & 84 & 111738 & $1.09(0.80-1.49)$ & 12 & 136885 & $1.58(0.62-4.03)$ \\
\hline $\begin{array}{l}\text { Second quartile } \\
(0-1.34 \%)\end{array}$ & 85 & 274004 & Reference & 78 & 136550 & Reference & 7 & 137454 & Reference \\
\hline $\begin{array}{l}\text { Third quartile } \\
(1.34-3.03 \%)\end{array}$ & 52 & 271266 & $0.79(0.56-1.13)$ & 50 & 121274 & $0.80(0.56-1.14)$ & 2 & 149992 & $0.27(0.06-1.29)$ \\
\hline $\begin{array}{l}\text { Fourth quartile } \\
(>3.03 \%)\end{array}$ & 32 & 271042 & $0.67(0.43-1.03)$ & 28 & 116123 & $0.57(0.36-0.88)$ & 4 & 154919 & $0.57(0.16-1.96)$ \\
\hline $\begin{array}{l}\text { Missing } \\
P \text { for trend }\end{array}$ & 77 & 213513 & $\begin{array}{c}1.54(1.12-2.12) \\
0.0019\end{array}$ & 65 & 91678 & $\begin{array}{c}1.39(0.99-1.95) \\
0.0009\end{array}$ & 12 & 121835 & $\begin{array}{c}2.20(0.85-5.69) \\
0.0132\end{array}$ \\
\hline $\begin{array}{l}\text { BMI change (\% per } \\
5 \text { years) - allowing } \\
\text { adjustment from } \\
\text { follow-up } \\
\text { measurement, if } \\
\text { any }{ }^{d} \text { (excluding } \\
\text { missing/extreme } \\
\text { values) }\end{array}$ & & & $0.86(0.81-0.92)$ & & & $0.89(0.83-0.95)$ & & & $0.74(0.64-0.86)$ \\
\hline \multicolumn{10}{|c|}{ 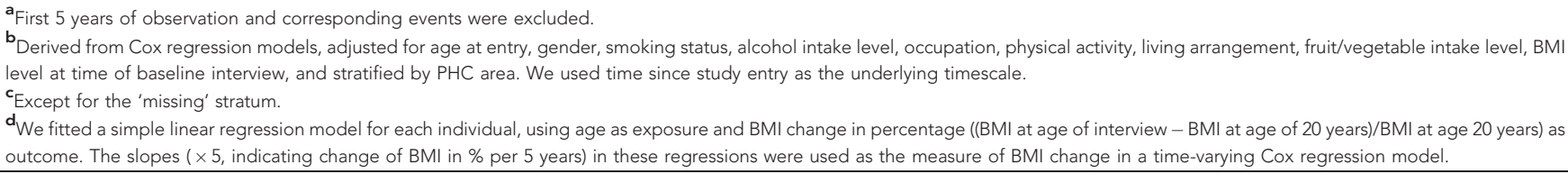 } \\
\hline
\end{tabular}

surveillance for cancer incidence from such a young age. Further, another study involving BMI change curves using both retrospectively self-reported and prospectively measured BMIs showed only a marginal difference in results when the prospective data were analysed alone, partly proving the reliability of these retrospective data (Arnold et al, 2016). Moreover, the nonresponse issue may have weakened the representativeness of the study population (Iwasaki et al, 2003). However, given the high response rate and the fact that our studied association did not seriously differ by those factors with uneven distributed between participants and non-participants (e.g., gender, occupation), the internal validity of our findings appears solid. Finally, owing to differences in lifestyle and ESCC incidence, the generalisation of our results to other populations remains uncertain.

In summary, our results suggest that an increase in BMI during adulthood is associated with a lower risk of developing ESCC among non-overweight subjects. Additionally, as the direction and magnitude of the association between BMI and ESCC varies by age, measurement of BMI level at recruitment together with data describing BMI change during adulthood might provide more accurate estimates on the studied association.

\section{ACKNOWLEDGEMENTS}

We thank the Iwate, Akita, Nagano, Ibaraki, Niigata, Osaka, Kochi, Nagasaki, and Okinawa Cancer Registries for providing their incidence data. We also thank the Japan Society for the Promotion of Science (JSPS) for providing a short-term postdoctoral fellowship to HS to support her research stay in Japan. This work was funded by the National Cancer Center Research and Development Fund (23-A-31(toku), 26-A-2).

\section{CONFLICT OF INTEREST}

MI is the beneficiary of a financial contribution from the AXA Research Fund as chair-holder of the AXA Department of Health and Human Security, Graduate School of Medicine, The University of Tokyo. The AXA Research Fund has no role in this work. The other authors declare no conflict of interest. 
Table 4. Hazard ratios (HRs) and $95 \%$ confidence intervals (Cls) for oesophageal squamous-cell carcinoma in relation to change in weight or body mass index (BMI), stratified by BMI level at baseline

\begin{tabular}{|c|c|c|c|c|c|c|}
\hline \multirow[b]{2}{*}{ Change in weight or BMI during adulthood } & \multicolumn{3}{|c|}{$\mathrm{BMI}<25 \mathrm{~kg} \mathrm{~m}^{-2}(n=69960)$} & \multicolumn{3}{|c|}{$\mathrm{BMI} \geqslant 25 \mathrm{~kg} \mathrm{~m}^{-2}(n=26371)$} \\
\hline & $\begin{array}{l}\text { Observed } \\
\text { cases }^{a}\end{array}$ & $\begin{array}{l}\text { Person- } \\
\text { years at } \\
\text { risk }^{a}\end{array}$ & $\begin{array}{l}\mathrm{HR} \text { and } 95 \% \\
\mathrm{Cl}^{\mathrm{b}}\end{array}$ & $\begin{array}{l}\text { Observed } \\
\text { cases }^{a}\end{array}$ & $\begin{array}{l}\text { Person- } \\
\text { years at } \\
\text { risk }^{a}\end{array}$ & $\begin{array}{l}\text { HR and } 95 \% \\
\mathrm{Cl}^{\mathrm{b}}\end{array}$ \\
\hline \multicolumn{7}{|l|}{ BMI level at age 20 years $^{c}$} \\
\hline $\begin{array}{l}<18.5 \mathrm{~kg} \mathrm{~m}^{-2} \\
18.5-24.9 \mathrm{~kg} \mathrm{~m}^{-2} \\
25-29.9 \mathrm{~kg} \mathrm{~m}^{-2} \\
\geqslant 30.0 \mathrm{~kg} \mathrm{~m}^{-2} \\
\text { Missing } \\
P \text { for trend }\end{array}$ & $\begin{array}{c}11 \\
196 \\
16 \\
3 \\
60\end{array}$ & $\begin{array}{c}86531 \\
656527 \\
39079 \\
3339 \\
139398\end{array}$ & $\begin{array}{l}0.68(0.37-1.25) \\
\quad \text { Reference } \\
1.22(0.73-2.04) \\
2.48(0.79-7.79) \\
1.57(1.16-2.12)\end{array}$ & $\begin{array}{c}4 \\
33 \\
9 \\
1 \\
9\end{array}$ & $\begin{array}{c}12201 \\
238068 \\
43104 \\
4847 \\
55354\end{array}$ & $\begin{array}{l}3.12(1.08-8.97) \\
\text { Reference } \\
1.22(0.58-2.57) \\
0.99(0.13-7.50) \\
1.35(0.63-2.91)\end{array}$ \\
\hline \multicolumn{7}{|l|}{ Weight change since age 20 years $^{c}$} \\
\hline $\begin{array}{l}\text { Loss }>5 \mathrm{~kg} \\
\text { Weight varied within } 5 \mathrm{~kg} \\
\text { Increase }>5 \mathrm{~kg} \\
\text { Missing } \\
P \text { for trend }\end{array}$ & $\begin{array}{c}56 \\
118 \\
56 \\
56\end{array}$ & $\begin{array}{l}103817 \\
354419 \\
297300 \\
169338\end{array}$ & $\begin{array}{l}1.52(1.10-2.12) \\
\text { Reference } \\
0.69(0.50-0.96) \\
1.16(0.82-1.65) \\
0.0002\end{array}$ & $\begin{array}{c}2 \\
5 \\
36 \\
13\end{array}$ & $\begin{array}{c}7979 \\
32425 \\
250978 \\
62192\end{array}$ & $\begin{array}{c}1.42(0.27-7.48) \\
\text { Reference } \\
1.35(0.51-3.53) \\
1.70(0.58-4.95) \\
0.8579\end{array}$ \\
\hline $\begin{array}{l}\text { BMI change (\% per } 5 \text { years) - between age } 20 \text { years and } \\
\text { baseline (excluding missing values) }\end{array}$ & & & $0.84(0.77-0.92)$ & & & $0.93(0.79-1.08)$ \\
\hline $\begin{array}{l}\text { First quartile }(<0 \%) \\
\text { Second quartile }(0-1.34 \%) \\
\text { Third quartile }(1.34-3.03 \%) \\
\text { Fourth quartile }(>3.03 \%) \\
\text { Missing } \\
P \text { for trend }\end{array}$ & $\begin{array}{l}90 \\
81 \\
35 \\
13 \\
67\end{array}$ & $\begin{array}{l}232373 \\
236567 \\
187956 \\
117180 \\
150798\end{array}$ & $\begin{array}{l}1.06(0.78-1.44) \\
\text { Reference } \\
0.68(0.45-1.01) \\
0.50(0.27-0.90) \\
1.57(1.13-2.19) \\
0.0015\end{array}$ & $\begin{array}{c}6 \\
4 \\
17 \\
19 \\
10\end{array}$ & $\begin{array}{c}16250 \\
37437 \\
83310 \\
153862 \\
62715\end{array}$ & $\begin{array}{l}3.19(0.89-11.4) \\
\text { Reference } \\
2.10(0.70-6.32) \\
2.04(0.67-6.22) \\
2.43(0.74-7.97) \\
0.8936\end{array}$ \\
\hline $\begin{array}{l}\text { BMI change (\% per } 5 \text { years) - allowing adjustment from } \\
\text { follow-up measurement, if any }{ }^{\mathbf{e}} \text { (excluding missing/extreme } \\
\text { values) }\end{array}$ & & & $0.85(0.79-0.92)$ & & & $1.03(0.88-1.19)$ \\
\hline \multicolumn{7}{|c|}{ 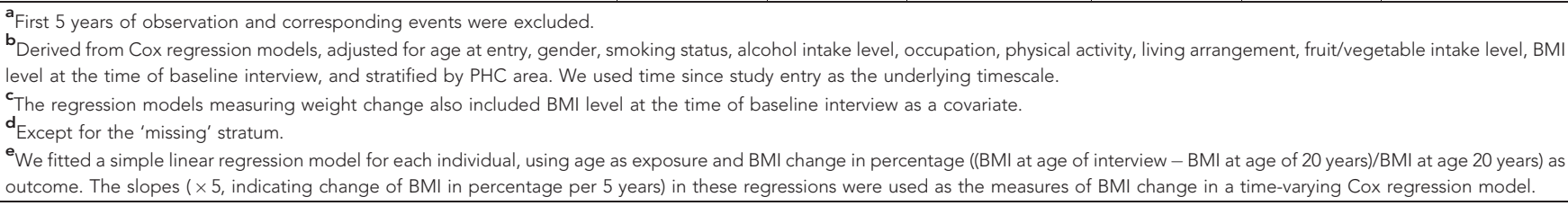 } \\
\hline
\end{tabular}

\section{REFERENCES}

Resl M, Zouhar M (1983) [ICD-O-Cs (International Classification of Diseases-Oncology- Czech edition)]. Cesk Patol 19(4): 228-250.

WHO (2000) International Classification of Diseases for Oncology, 3 edn. World Health Organization: Geneva, Switzerland.

Abnet CC, Freedman ND, Hollenbeck AR, Fraumeni Jr. JF, Leitzmann M, Schatzkin A (2008) A prospective study of BMI and risk of oesophageal and gastric adenocarcinoma. Eur J Cancer 44(3): 465-471.

Abnet CC, Lai B, Qiao YL, Vogt S, Luo XM, Taylor PR, Dong ZW, Mark SD, Dawsey SM (2005) Zinc concentration in esophageal biopsy specimens measured by x-ray fluorescence and esophageal cancer risk. J Natl Cancer Inst 97(4): 301-306.

Arnold M, Jiang L, Stefanick ML, Johnson KC, Lane DS, LeBlanc ES, Prentice R, Rohan TE, Snively BM, Vitolins M, Zaslavsky O, Soerjomataram I, Anton-Culver H (2016) Duration of adulthood overweight, obesity, and cancer risk in the women's health initiative: a longitudinal study from the United States. PLoS Med 13(8): e1002081.

Bahmanyar S, Ye W (2006) Dietary patterns and risk of squamous-cell carcinoma and adenocarcinoma of the esophagus and adenocarcinoma of the gastric cardia: a population-based case-control study in Sweden. Nutr Cancer 54(2): 171-178.

Bianchini F, Kaaks R, Vainio H (2002) Overweight, obesity, and cancer risk. Lancet Oncol 3(9): 565-574.

Engel LS, Chow WH, Vaughan TL, Gammon MD, Risch HA, Stanford JL, Schoenberg JB, Mayne ST, Dubrow R, Rotterdam H, West AB, Blaser M, Blot WJ, Gail MH, Fraumeni JF (2003) Population attributable risks of esophageal and gastric cancers. J Natl Cancer I 95(18): 1404-1413.

Engeland A, Tretli S, Bjorge T (2004) Height and body mass index in relation to esophageal cancer; 23-year follow-up of two million Norwegian men and women. Cancer Causes Control 15(8): 837-843.
Fan Y, Yuan JM, Wang R, Gao YT, Yu MC (2008) Alcohol, tobacco, and diet in relation to esophageal cancer: the Shanghai Cohort Study. Nutr Cancer 60(3): 354-363.

Ferlay J, Soerjomataram I, Dikshit R, Eser S, Mathers C, Rebelo M, Parkin DM, Forman D, Bray F (2015) Cancer incidence and mortality worldwide: sources, methods and major patterns in GLOBOCAN 2012. Int J Cancer 136(5): E359-E386.

Han XS, Stevens J, Truesdale KP, Bradshaw PT, Kucharska-Newton A, Prizment AE, Platz EA, Joshu CE (2014) Body mass index at early adulthood, subsequent weight change and cancer incidence and mortality. Int J Cancer 135(12): 2900-2909.

Hu JX, Thomas CE, Brunak S (2016) Network biology concepts in complex disease comorbidities. Nat Rev Genet 17(10): 615-629.

Iwasaki M, Otani T, Yamamoto S, Inoue M, Hanaoka T, Sobue T, Tsugane S. Group JS (2003) Background characteristics of basic health examination participants: the JPHC Study Baseline Survey. J Epidemiol 13(4): 216-225.

Jessri M, Rashidkhani B, Hajizadeh B, Jessri M, Gotay C (2011) Macronutrients, vitamins and minerals intake and risk of esophageal squamous cell carcinoma: a case-control study in Iran. Nutr J 10: 137.

Kort EJ, Sevensma E, Fitzgerald TL (2009) Trends in esophageal cancer and body mass index by race and gender in the state of Michigan. BMC Gastroenterol 9: 47.

Kruk J (2014) Overweight, obesity, oxidative stress and the risk of breast cancer. Asian Pac J Cancer Prev 15(22): 9579-9586.

Lahmann PH, Ibiebele TI, Webb PM, Nagle CM, Whiteman DC. Australian Cancer Study (2014) A case-control study of glycemic index, glycemic load and dietary fiber intake and risk of adenocarcinomas and squamous cell carcinomas of the esophagus: the Australian Cancer Study. BMC Cancer 14: 877 .

Lahmann PH, Pandeya N, Webb PM, Green AC, Whiteman DC. Australian Cancer Study (2012) Body mass index, long-term weight change, and 
esophageal squamous cell carcinoma: is the inverse association modified by smoking status? Cancer 118(7): 1901-1909.

Launoy G, Milan C, Day NE, Pienkowski MP, Gignoux M, Faivre J (1998) Diet and squamous-cell cancer of the oesophagus: a French multicentre case-control study. Int J Cancer 76(1): 7-12.

Matsushita Y, Takahashi Y, Mizoue T, Inoue M, Noda M, Tsugane S, Grp JS (2008) Overweight and obesity trends among Japanese adults: a 10-year follow-up of the JPHC Study. Int J Obesity 32(12): 1861-1867.

O'Doherty MG, Freedman ND, Hollenbeck AR, Schatzkin A, Murray LJ, Cantwell MM, Abnet CC (2012) Association of dietary fat intakes with risk of esophageal and gastric cancer in the NIH-AARP diet and health study. Int J Cancer 131(6): 1376-1387.

Park SL, Lee YCA, Marron M, Agudo A, Ahrens W, Barzan L, Bencko V, Benhamou S, Bouchardy C, Canova C, Castellsague X, Conway DI, Healy CM, Holcatova I, Kjaerheim K, Lagiou P, Lowry RJ, Macfarlane TV, Macfarlane GJ, McCartan BE, McKinney PA, Merletti F, Pohlabeln H, Richiardi L, Simonato L, Sneddon L, Talamini R, Trichopoulos D, Znaor A, Brennan P, Hashibe M (2011) The association between change in body mass index and upper aerodigestive tract cancers in the ARCAGE project: multicenter case-control study. Int J Cancer 128(6): 1449-1461.

Pennathur A, Gibson MK, Jobe BA, Luketich JD (2013) Oesophageal carcinoma. Lancet 381(9864): 400-412.

Smith M, Zhou M, Whitlock G, Yang G, Offer A, Hui G, Peto R, Huang Z, Chen Z (2008) Esophageal cancer and body mass index: results from a prospective study of 220000 men in China and a meta-analysis of published studies. Int J Cancer 122(7): 1604-1610.

Sterne JAC, White IR, Carlin JB, Spratt M, Royston P, Kenward MG, Wood AM, Carpenter JR (2009) Multiple imputation for missing data in epidemiological and clinical research: potential and pitfalls. $\mathrm{Br}$ Med J 339: b2393.

Tamakoshi A, Yatsuya H, Lin Y, Tamakoshi K, Kondo T, Suzuki S, Yagyu K, Kikuchi S. Group JS (2010) BMI and all-cause mortality among Japanese older adults: findings from the Japan collaborative cohort study. Obesity (Silver Spring) 18(2): 362-369.

Taylor PR, Qiao YL, Abnet CC, Dawsey SM, Yang CS, Gunter EW, Wang W, Blot WJ, Dong ZW, Mark SD (2003) Prospective study of serum vitamin E levels and esophageal and gastric cancers. J Natl Cancer Inst 95(18): 1414-1416.

Tran GD, Sun XD, Abnet CC, Fan JH, Dawsey SM, Dong ZW, Mark SD, Qiao YL, Taylor PR (2005) Prospective study of risk factors for esophageal and gastric cancers in the Linxian general population trial cohort in China. Int J Cancer 113(3): 456-463.

Tsugane S, Sawada N (2014) The JPHC study: design and some findings on the typical Japanese diet. Jpn J Clin Oncol 44(9): 777-782.

Winter JE, MacInnis RJ, Wattanapenpaiboon N, Nowson CA (2014) BMI and all-cause mortality in older adults: a meta-analysis. Am J Clin Nutr 99(4): 875-890.

Yang P, Zhou Y, Chen B, Wan HW, Jia GQ, Bai HL, Wu XT (2009) Overweight, obesity and gastric cancer risk: results from a meta-analysis of cohort studies. Eur J Cancer 45(16): 2867-2873.

This work is published under the standard license to publish agreement. After 12 months the work will become freely available and the license terms will switch to a Creative Commons AttributionNonCommercial-Share Alike 4.0 Unported License.

Supplementary Information accompanies this paper on British Journal of Cancer website (http://www.nature.com/bjc) 